\title{
Professional Competences. \\ Reconstruction of the Opinions of Polish Female Directors
}

\author{
Monika Modrzejewska-Świgulska \\ University of Lodz, Poland \\ E-mail address: momodrzejewska@gmail.com
}

\section{ARTICLE INFO}

\section{Keywords:}

Directing skills

Polish female film directors

Qualitative research

Model of the function of a director

Article history:

Received 18 May 2018

Received in revised form 28 May 2018

Accepted 05 June 2018

ISSN: 2354-0036

DOI: $10.1515 /$ ctra-2018-0005
A B STRACT

The aim of this work is to reconstruct the convictions and opinions of Polish female film directors concerning work competences that actuate work and success in the field of film directing. Qualitative data are presented in the text, which were collected by the Author herself in free interviews carried out with twelve Polish female film directors.

\section{INTRODUCTION}

For a long time, film and theatre direction used to be among the most masculine of artistic professions. The absence of women in Polish theatre and cinema might have been connected with unwritten rules in the film industry, e.g. that women were delegated to more creative tasks, but ones of less significance (e.g. to make documentaries, films for children and youth), female directors played supportive roles (e.g. $2^{\text {nd }}$ unit directors, producers), or they would come across some very hostile conditions (e.g. negative convictions concerning their predispositions for becoming a director or not being taken seriously) (Tomasik, 2004; Talarczyk-Gubała 2013a, 2013b, 2015; Wejbert-Wąsiewicz, 2015). Talarczyk-Gubała (2013) draws attention to a systemic mechanism that might have influenced a small number of female directors. According to her, misogyny is overwhelming in the circles of the film and theatre environment - starting with education at the Łódź Film and Theatre School, the most famous Polish school educating professionals connected with film and theatre, through the allocation of funds for the production of original projects. This is well summarised by a representative of one of the older generation of female di- 
rectors: We had this professor back at school, who thought that a man has a synthetic mind and a woman an analytical one and with such a brain she's completely not suited for this profession because film directing is a synthetic activity. Currently, thanks to social and cultural changes and the policy of equality, much has changed in favour of women, particularly when it comes to the issue of discrimination in education for the profession. However, what remains unchanged, are the social expectations and patterns of female behaviour (Talarczyk-Gubała 2013a, 2013 b, 2015; Wejbert-Wąsiewicz, 2015).

Numerical data make it possible to conclude that there is indeed an increase in film productions made by women in Poland. In the 70 s and 80 s only three female directors managed to make a name for themselves in Polish feature films: Barbara Sass, Agnieszka Holland and Magdalena Łazarkiewicz. Even an interesting debut was not aguarantee that they would be sustained in the profession for many female directors, as emphasized by Tomasik (2004). Since 2006, the Polish cinematography system has included scholarships and script competitions: "30 minut", "Pierwszy dokument". Thanks to these initiatives, within 10 years, 21 female directors from the younger generation received funding for their short films (e.g. Agnieszka Smoczyńska, Barbara Białowąs, Katarzyna Jungowska, Maria Sadowska). Most of them made their debut with a full-length film. Between 2006 - 2015, female directors made $28 \%$ of all the productions in total, including full -length feature films which made up $12 \%, 29 \%$ of the total were short feature films, $30 \%$ documentaries and 28\% were film animations (Talarczyk-Gubała, 2016).

\section{METHODS AND RESEARCH CONTEXT}

In this article, I present the research assumptions and methodological and interpretation decisions resulting from the qualitative material gathered in my research. The quoted results of the research are hypotheses and preliminary interpretations, since I am still in the process of collecting and analysing the empirical data. The prepared interpretations are, however, so theoretically saturated that they may take on the form of a preliminary report from the study.

I became curious about how female directors themselves see their professional situation and the nature of their subjective experiences connected with existing in the world of theatre and film. Inspired by the research works of Gruber (1989) and his disciples, I made it my research aim to reconstruct the professional paths of Polish female film directors and to put forward the following question: what do Polish female film directors do to become known in the world of theatre and film? And what activities do they undertake to develop professionally? What biographical experiences do they recall in their stories about their professional paths? The above assumptions required appropriate methods for collecting empirical data that would make it possible to recognise the perspective 
and system of meanings of my interlocutor and, as a consequence, to build a theory based on biographical data. This is why in my research project, I applied a qualitative research tool - interviews, analysis of documents (memories, interviews) and observation. In interviews concerning the development of professional oath, the topic that was most often touched upon was the issue of directing competences and skills. Hypothetically, it may be assumed that it is a reaction to the myths that are present in the film environment and which preserve the false conviction that women lack certain predispositions that would enable them to perform the profession of a film director. This article aims at highlighting the convictions and opinions of female film directors that concern precisely the competences used in the profession of a film director. I assume that knowing what conditions professional competences may sensitize female directors to the areas that need to be strengthened and developed in order to achieve professional success.

\section{Research participants}

Twelve Polish female film directors participated in the interviews; all of them work as film, theatre or TV directors. They are professionally active students or graduates of artistic schools. My interlocutors completed artistic schools at different times, the oldest of them in the 50 s of the previous century and the youngest at the onset of the $21^{\text {st }}$ century. All of them live and work in Poland.

\section{Research instruments - leading techniques}

In my research I applied a semi-structured interview because it enabled me to concentrate on the selected aspects of my study. Additionally, semi-structured interviews provide the interlocutors with space to present their own perspective and allow them to bring up issues relevant to them and connected with the topic initiated by the researcher (Kvale, 2004; Flick, 2011; Kaufman, 2010). My interviews were always started with a general question - Please, tell me about the history of your professional path, how did it happen that you became a film director. Despite openness and flexibility, which is normally the case in free interviews, applying these techniques does not mean that complete freedom of response results and that the interview does not require preparation and the skill of adjusting the order of the questions to the dynamics of the conversation led by the interviewer (Kvale, 2004; Kaufman 2010; Flick 2011). During the interview I asked for the following questions to be clarified:

The course of their professional path - stages, turning points/events that changed the direction of their professional path, strategies for steering one's own career and dealing with obstacles;

Subjectively the most important areas in their artistic work and ways in which it was organised - strategies connected with organising an artist's work from the moment 
an idea is born, through communicating it to a broader audience, its realisation, everyday and occasional practices that actuate the course of artistic actions (e.g. plans, meetings, random events), the skills and abilities necessary in the work of a director;

The importance of the artistic environment for professional biography - patterns of interactions and relations, people important to the professional biography, the significant others, network of connections, rules and regulations ruling a given society as opposed to individual professional paths; patterns of adjustments (or lack of them) to the professional role, resistance towards regulations;

Education and its subjective meaning in being a creator - developing interests connected with the area of creativity, importance of academic education from the perspective of professional experiences;

Importance of family environment for the development of artistic interests and the choice of the area of creativity, professional family patterns;

Defining oneself as a representative of a given profession in the context of other roles/areas of life - combining creative work with other areas of life, artistic work and personal life;

Socio-historical background/group contexts - global events and the course of individual professional stories of female directors in a broader context.

The content of interviews carried out with the female directors is the basis of the interpretation suggested here. The interviews provide a direct record of meanings that the female creators give to their activities, experiences and events. This means that my interpretation remains within the frames created by the narrators themselves.

\section{Research instruments - supplementary techniques}

Collecting data was complemented by carrying out observations concerning the participant, which is one of the most basic techniques applied in social sciences (Lutyński 2000). The characteristic features of this technique include becoming familiar with the "natural" environment of the studied subjects and making direct contact with the participants (Konecki, 2000; Lutyński 2000). Carrying out observations makes it possible to become familiar with, and understand, the context in which processes connected with a selected area of creativity take place, and here it is film directing (Konecki, 2000; FrankfortNachmias, Nachmias 2002). I carried out my observations on film sets (of a TV series with a history of several years and a feature film), I also participated in rehearsals of a professional off-theatre.

In my studies, I also employed already existing (auto)biographical materials memories, interviews, press articles on the works of the female directors. The already ex- 
isting materials by the artists themselves, I understand as a social communication practice, I assume they are a record of a certain social awareness and thus are an appropriate material to complement the content of interviews. In the already existing materials I was looking for similar topics that were discussed by the interlocutors, therefore I treat them as a way of triangulating data acquired through direct conversation.

\section{PROCEDURE FOR THE INTERPRETATION OF THE RESEARCH MATERIAL}

The recorded interviews were transcribed and interpreted. Interpretation was three-fold, based on the suggestion of Denzin (1990):

(1) analysis of the narration for one story/ case interpretation;

(2) collecting group narrations that could be grouped around common biographical threads;

(3) comparative analysis of stories of the studied people/ women-directors.

\section{Results of research - competences in the work of a director and creative tasks}

In the stories told by the female directors there appeared ideas concerning professional competences. According to the interlocutors, it is possible to identify three types of competences in a director, and they are as follows: 1) Leadership/organizational competences, 2) Creative competences and 3) Craft/professional competences. Each of these competences is imbued by the directors with individual values. They state these both in a straightforward way or indirectly - by talking about realised tasks and professional projects (see Table 1). Additionally, the directors emphasise the dynamics, functions and hierarchical order of professional competences. This means that, depending on the aim and nature of the professional task, the interlocutors referred to the three types of the above mentioned competences with various degrees of intensification. Thus, the more complex and multi-aspected the task was (e.g. making a film based on an original script, a novel adaptation for the theatre), the more important it became to combine and apply all three types of competences in a more dynamic way.

In the directors' narrations competences were seen in hierarchical terms as leadership, artistic and technical competences became more dynamic and were triggered by their personal predispositions. The first ones are, in the opinion of the directors, very likely to be trained and taught - especially those to do with leadership and craft, whereas those related to personality are simply impossible to learn. And it is precisely the personality predispositions that, to a great extent, decide about professional success and the ability to deal with difficult situations that are so frequently encountered at work by the female directors. They understand personality predispositions as high psychological resilience to stress and unexpected situations, in other words, a director needs a skill that 
helps to come out unscathed from depressing and embarrassing situations (such as being criticised for their ideas in a group). The female directors emphasised the importance of psychological resilience when faced with an entry exam situation. It was the ability to deal with stress and react appropriately to absurd tasks during the entry exams at a Faculty of Directing that are decisive about the success or otherwise of the result.

Table 1.

Competences of a director in the opinions of female directors

\begin{tabular}{|c|c|c|}
\hline $\begin{array}{l}\text { LEADERSHIPI ORGANISATION } \\
\text { Director as } \\
\text { "leader"/"corporal"'/"accountant"1 } \\
\text { Features: }\end{array}$ & $\begin{array}{c}\text { CREATIVE } \\
\text { Director as } \\
\text { "poet"/"creator"2/ the inspiration } \\
\text { Features: }\end{array}$ & $\begin{array}{l}\text { CRAFT/ PROFESSIONAL } \\
\text { Director as } \\
\text { "professional/"craftsman"3 } \\
\text { Features: }\end{array}$ \\
\hline $\begin{array}{l}\text { Managing a theatre/film crew } \\
\text { - planning the work of the } \\
\text { team; } \\
\text { Moderating the team } \\
\text { Responsibility for organising } \\
\text { the set/rehearsals; } \\
\text { Adhering to agreed schedu- } \\
\text { les; } \\
\text { Agreeing the financial condi- } \\
\text { tions with producers; } \\
\text { Adhering to the schedule of } \\
\text { others and planning their } \\
\text { work; } \\
\text { Building the team. }\end{array}$ & $\begin{array}{l}\text { - } \quad \begin{array}{l}\text { Searching for intriguing sto- } \\
\text { ries; }\end{array} \\
\text { Brave investment in surprising } \\
\text { and original topics; } \\
\text { - } \quad \text { Looking for surprising associ- } \\
\text { ations and meanings; } \\
\text { - } \quad \text { Inspiring others; } \\
\text { - } \quad \text { Realising original ideas. }\end{array}$ & $\begin{array}{l}\text { - Applying artistic craft in } \\
\text { film and theatre; } \\
\text { Applying poetic means } \\
\text { characteristic of film } \\
\text { and theatre; } \\
\text { - } \quad \text { Applying various con- } \\
\text { ventions; } \\
\text { Using domain } \\
\text { knowledge. }\end{array}$ \\
\hline
\end{tabular}

Taking care of the quality of the final product/bearing the responsibility

Note: My own study, description of the features on the basis of opinions of female directors

And here are some of the opinions of the female film directors:

A director is a poet and a corporal in one, this is Andrzej Wajda's opinion quoted by the next generations of female directors;

I think that the work of a director also includes knowing exactly what other teams do and what they are responsible for in the theatre or film. I mean, you need to know what to work on with the actors, what to do with the stage designer, you need to be able to pull those strings in parallel so as to be able to pull them tight at the same time, it's connected with the ability to see the bigger picture and plan everything.

A director is a craftsman who has the capacity to create the world on stage and the more convincing this world is, the better a craftsman-director you are.

\footnotetext{
${ }^{1}$ from the statements of female directors

2 from the statements of female directors

${ }^{3}$ from the statements of female directors
} 
Summarising metaphorically using the words of my interlocutors, "a poet" and "a craftsman" know what they want to talk about and how to do it, they are responsible for the aesthetic quality and the multidimensionality of the result of their creative work. "A corporal", on the other hand, is able to organise the work of others, convince those people who make decisions about the value of their ideas and consequently, make the ideas happen.

\section{The function of a director and directing abilities}

The model of the function of a director presented here was made on the basis of a recurring narration in the interviews with female directors. The model presented below requires further exploration and incorporation of more data, it is of a hypothetical and temporary character (Figure 1). Female directors emphasise the variety of functions of a director, depending on what matter they are working with and the creative activities involved. Since directing is not just realising tasks that are of a highly autonomous and free character, but also realising ready-made ideas (e.g. directing the screenplay of another episode of a TV series). The first projects are described by the female directors as more creative ones because they include the whole process of creating a work: from its first appearance as an idea, through verbalisation, confrontation with the environment and finally to being realised (e.g. an original idea for a film or a performance, an original and free theatre adaptation). The creative aims and tasks are highly significant in determining the range of opinions of other people, such as the members of the theatre or film crew (e.g. actors, camera operators, stage designers) which are included and considered.

The model of the function of a director is based on two dimensions that lay out four basic functions of a director in the process of creating her work. The first dimension concerns the aim of her creative work and is based on it - a weakly structured - a structured aim (the vertical line) (Figure 1):

- $\quad$ From no clearly defined aim and, as a consequence, no structure or clear content of the task, the aim appears during the course of work;

- To a very specific verbalised aim, often written down.

The second dimension of the model is described by the range and intensity of including others in the process of making decisions, i.e. the dynamics of team work. This is done through - from others - to and with others (the horizontal line) (Figure 1):

- The style of work from others determines the visionary who realises his/her idea in an ex cathedra form, with the help of the competences of others, e.g. actors, camera operators, technicians, stage designers; 
- $\quad$ The other end of the dimension to and with others pictures a director who works in a democratic way, and inspires people to work together and discuss their ideas. Such a director realises tasks with other people and thanks to their creative competences. In the opinion of female directors, such a style works best in non-structured situations and in team work (e.g. low-budget productions or in short commercial tasks such as commercials).

It needs to be emphasised that this is merely a model and every task of the director may be realised with a greater or lesser openness to the ideas of others, and this is a matter of the director's decision and his/her openness.

At the cross-section of the two dimensions described above, there are four categories of types of tasks and professional competences that are dynamically applied, and as a consequence - four functions of a director - the inspirational, the creative and innovative, the organisational and that of combining ideas (Figure 1) .

The inspirational function is best seen while working on a weakly structured aim to and with others (1). The director is more of a moderator and an inspiration here, than a lonely creator working on his/her original idea. He or she places more emphasis on relationships and synergic team work. The aim of the artistic work is the result of intense co -operation of the director and other theatre or film crew members. The work has a relational and interactive character, it is realised through dynamic discussions within the team. The female directors emphasized that there is no ready-made idea, but that the idea evolves during the course of team work, which is connected with the rotation of a director's role, as well as that of other team members. During such work, the directors usually trigger off their leadership skills and take care of the democratic space for cooperation. The artistic value of the product depends on the competences and professional experiences of the whole team.

I had the opportunity to observe this type of work during a final rehearsal for a spectacle prepared by the only professional female theatre in Poland, The Artistic Teraz Poliż Group.

\section{An example of a democratizing dialogue during theatre team work:}

Director: What do you think?

Actress one: There is something unclear in that scene.

Director: But what?

Actress two: I don't know why this fairy is talking to the children instead of following their ideas.

Director: And what would you do?

Actress two: l'd cut this scene out and open up to the voices from the audience.

Director: Let's do it again, then. 
According to Sawyer $(2009,2010)$ creative activity is highly interactiveand requires co-operation; the researcher uses such terms as creative collaboration and deeply collaborative activity. In his opinion, this is particularly true for contemporary forms of creativity, such as film and TV productions. The female directors are aware of this and they emphasize the team and relational character of a director's work - at every stage, starting with searching for ideas, through to realising the final product.

Situations of the second kind - weakly structured aim - from others (2) - here it is the director who makes the decisions and follows his/her own vision, rarely including ideas and suggestions from the team. The relationships within the team may be formal and hierarchical, which results in the intransitivity of the roles of a director and the team members. Everyone realises their own typical professional role - an actor plays, the lighting technician deals with light. The role of others here is limited to fulfilling the roles outlined by the aim.

A structured aim - from others (3) - also has a highly structured aim thanks to a ready script and a screenplay, a director must manage the team for a given plan to be realised on time. The director's function is limited to co-ordination and control; such work leaves little space for his/her, or other team members' creativity.

Every function of combining ideas is connected with work - structured aim - to and with others (4). Such a situation concerns projects with a clear creative aim and the realisation is based on the intense work of the team, original ideas are added to the ideas of other team members. The director chooses the original ideas and combines them into one meaningful story / whole. Here, the director applies mostly his/her leadership and craftsmanship skills to assess the quality of a ready product aesthetically. 


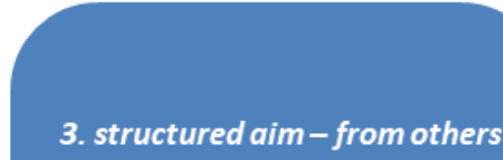

Creative aim: TV series, directing

ready-made scripts (film,

television theatre)

Applied abilities: leadership and craftsmanship

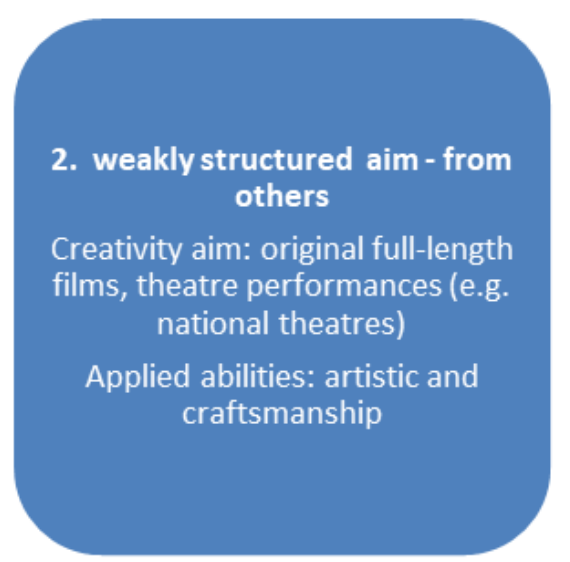

Note: My own study

FIGURE 1. The function of a director and directing abilities

In summary, I had the opportunity to conduct free observation of directors on film sets, where the quality and manner of work was radically different, depending on the type of production - feature film, TV series. The role of a director on the set of a TV series was more limited to watching and making sure that all the scenes planned for the day were filmed. Their work was to manage and supervise and the director herself was more focused on completing the task than building relations with the team or actors. During the interviews, one of the directors emphasised: In a TV series, a director is pushed into the function of a person who organises the set, there are sometimes such suggestions coming from the producer. Work on the set of a feature film gives more possibilities to work with the actors and to demonstrate the creative skills of the director, discuss things with the team, search for solutions together, delegate responsibilities to others or just go with the spontaneous reactions of the film crew.

\section{DISCUSSION}

Researchers of creativity writing about the systemic approach are very consistentin deconstructing the myth of a lonely creator who is backed up solely by his/her own ideas, 
talent and experience. In common opinion, creative work is mostly associated with the final result (a picture, a poem, a piece of music) or the genius of the creator. In reality, however, it is far more complex than is commonly thought. In order to communicate his/ her ideas and give them some tangible shape, a creator undertakes many co-ordinated and heteronomous activities and this is what the female directors tried to convey. In the narrations of Polish female directors, this diversity of activities is usually aimed at building a net of contacts and environmental relationships, co-operation with other creators or fostering their own creation and planning other creative projects. The final result of their creative work is the effect of individual and group activities and this is probably the reason why in the minds of my interlocutors, a director should present a range of competences and appropriate personality predispositions.

\section{REFERENCES}

Denzin, N. K. (1990). Reinterpretacja metody biograficznej w socjologii: znaczenie a metoda $w$ analizie biograficznej. In J. Włodarek, M. Ziołkowski (Eds.). Metoda biograficzna w socjologii. [Biographical Method in Sociology]. Warszawa: PWN.

Flick, U. (2011). Jakość w badaniach jakościowych. [Managing Qulity in Qualitative Reserch]. Warszawa: PWN.

Frankfort-Nachmias, Ch., Nachmias, D. (2001). Metody badawcze w naukach społecznych. [Research Methods in the Social Sciences]. Poznań: Wydawnictwo Zysk i S-k.

Gruber, H. E. (1989). The Evolving Systems Approach to Creative Work. In: H. E. Gruber, D. B. Wallace (Eds.), Creative People at Work, New York - Oxford: Oxford University Press.

Konecki, T. K. (2000). Studia z metodologii badań jakościowych. Teoria ugruntowana. [Qualitative Research. Grounded Theory]. Warszawa: PWN.

Kaufman, J.-C. (2010). Wywiad rozumiejący. [Understanding Interview]. Warszawa: Oficyna Naukowa.

Kvale, S. (2004). Interviews. Wprowadzenie do jakościowego wywiadu badawczego. [InterViews. An Introduction to Qualitative Research Interviewing]. Białystok: Trans Humana.

Kvale, S. (2010). Prowadzenie wywiadów. [Doing Interviews]. Warszawa: PWN .

Lutyński, J. (2000). Metody badań społecznych. [Social Methods Research]. Łódź: Łódzkie Towarzystwo Naukowe.

Talarczyk-Gubała, M. (2013a). Biały mazur. Kino kobiet w polskiej kinematografii. Poznań: Galeria Miejska Arsenał. 
Talarczyk-Gubała, M. (2013b). Wszystko o Ewie. Filmy Barbary Sass a kino kobiet w drugiej połowie XX wieku. [Everything about Ewa. Barbara Sass's films and women's cinema in the second half of the twentieth century]. Szczecin: US.

Talarczyk-Gubała, M. (2015). Wanda Jakubowska. Od nowa. [Wanda Jakubowska. A new]. Warszawa: Krytyka Polityczna.

Talarczyk-Gubała, M. (2016). Pilotażowy raport o pozycji kobiet w polskiej kinematografii. Fakty i liczby. Krytyka Polityczna, http://krytykapolityczna.pl/file/2016/06/Raport Monika_Talarczyk_Gubala.pdf, [access 11.2017]

Tomasik, K. (2004). Polskie reżyserki filmowe 1919 - 2002. [Polish women film directors 1919 - 2002]. Kultura i Historia, 6, http://www.kulturaihistoria.umcs.lublin.pl/ archives/179, [access 12.2017].

Sawyer, K. (2009). Writing as a Collaborative Act. In S. B. Kaufman, J.-C. Kaufman (Ed.). The Psychology of Creative Writing. New York: Cambridge University Press.

Sawyer, K. (2010). Individual and Group Creativity. In J. C. Kaufman, R. J. Sternberg (Eds). The Cambridge Handbook of Creativity. New York: Cambridge University Press.

Wejbert-Wąsiewicz, E. (2015). Niepokorne reżyserki kina polskiego. In I. Desperak, I. Kuźmy (Eds.). Kobiety niepokorne. Reformatorki - Buntowniczki - Rewolucjonistki. [The undefiled women of the Polish cinema director. In Rebellious Women. Reformers - Rebels Revolutionists]. Łódź: UŁ.

Corresponding author at: Monika Modrzejewska-Świgulska, University of Lodz, Zakład Pedagogiki Twórczości, 46/48 Pomorska St., 91-408 Łódź, Poland E-mail: momodrzejewska@gmail.com 